\title{
PERENCANAAN DIGITALISASI PERPUSTAKAAN PADA UPT PERPUSTAKAAN UNIVERSITAS HALU OLEO
}

\author{
Juniati ${ }^{1}$ Zulfiah Larisu ${ }^{2}$, La Iba ${ }^{3}$ \\ Ilmu Komunikasi Konsentrasi Perpustakaan Fakultas Ilmu Sosial dan Ilmu Politik Universitas Halu Oleo, \\ Kendari. Indonesia \\ Email: indhajun@gmail.com
}

\begin{abstract}
ABSTRAK
"Perencanaan Digitalisasi Perpustakaan pada UPT Perpustakaan Universitas Halu Oleo". Program Studi Perpustakaan dan Ilmu Informasi Fakultas Ilmu Sosial dan Ilmu Politik Universitas Halu Oleo. Pembimbing I Dr. Zulfiah Larisu, S.Sos., M.Si. dan Pembimbing II La Iba, S.Ip., M.Si. Tujuan penelitian adalah untuk mengetahui perencanaan digitalisasi perpustakaan pada UPT Perpustakaan Universitas Halu Oleo.Teknik analisis data yang digunakan dalam penelitian ini dilakukan secara deskriptif kualitatif. Subjek atau informan penelitian berjumlah 3 orang yang terdiri dari pengelola pustaka elektronik dan pustakawan. Teknik pengumpulan data berupa observasi, wawancara dan dokumentasi. Hasil penelitian ini menunjukkan bahwa perencanaan digitalisasi perpustakaan pada UPT Perpustakaan Universitas Halu Oleo sejauh ini dari segi indikator jaringan, fasilitas, sumber daya manusia dan pemantauan evaluasi kinerja sudah cukup maksimal. Tetapi dari indikator tersebut adanya indikator yang belum bisa dikatakan maksimal yaitu pendanaan. Proses pendanaan yang berasal dari pemerintah dalam hubungannya dengan pihak penyelenggara perpustakaan atau pihak Universitas tidak menjamin proses pendanaannya ada untuk setiap tahunnya, sedangkan perencanaan digitalisasi membutuhkan dana yang cukup besar untuk menunjang prosesnya. Keputusan pendanaan merupakan salah faktor yang cukup serius dalam proses digitalisasi perpustakaan pada UPT Perpustakaan Universitas Halu Oleo.
\end{abstract}

Kata Kunci : Perencanaan, Digitasilisasi perpustakaan

\begin{abstract}
Juniati (C1D4 15 093), "Planning for Library Digitalization at Halu Oleo University Library". Library and Information Science Study Program, Faculty of Social and Political Sciences, Halu Oleo University. Advisor I Dr. Zulfiah Larisu, S.Sos., M.Si. and Supervisor II La Iba, S.Ip., M.Si. The research objective was to determine the planning for digitalization of the library at the Halu Oleo University Library. The data analysis technique used in this study was carried out descriptively qualitatively. Subjects or research informants totaled 3 people consisting of electronic library managers and librarians. Data collection techniques in the form of observation, interviews and documentation. The results of this study indicate that the planning for digitalization of the library at the UPT Library of Halu Oleo University so far has been maximal in terms of network indicators, facilities, human resources and monitoring performance evaluation. But from these indicators, there are indicators that cannot be said to be maximum, namely funding. The funding process that comes from the government in conjunction with the library organizer or the university does not guarantee that the funding process is there every year, while digitalization planning requires a large enough fund to support the process. The funding decision is a serious factor in the process of digitizing the library at the Halu Oleo University Library.
\end{abstract}

Key Words : Planning, Library digitization 


\section{PENDAHULUAN}

Perencanaan adalah kegiatan-kegiatan pengambilan keputusan dari sejumlah pilihan mengenai sasaran dan cara-cara yang akan dilaksanakan di masa depan guna mencapai tujuan yang diinginkan, serta pemantauan dan penilaian atas perkembangan hasil pelaksanaannya, yang dilakukan secara sistematis dan berkesinambungan.

Perencanaan perpustakaan ini bertujuan untuk menyediakan arahan dan kerangka kerja perpustakaan yang akan memandu pengambilan keputusan dan pemecahan masalah, Meningkatkan layanan perpustakaan melalui control pelaksanaan kegiatan dan penggunaan anggaran, Untuk memastikan pengembangan yang rasional dan efektif baik bagi sumber-sumber informasi yang menjadi koleksi perpustakaan, Memungkinkan menggantisipasi kebutuhan sumber-sumber informasi dengan cara membuat perencanaan keadaan saat ini dan proyeksi keadaan di masa datang, dan Memberikan pengalaman dan keahlian bagi pustakawan dalam membuat perencanaan.

Informasi berbasis kertas (paper-based), yang selama ini menjadi primadona perpustakaan, sekarang semakin banyak yang tersedia dalam bentuk digital atau edisi elektronik. Bahkan sebagian dari produk informasi yang dihasilkan, telah ada yang hanya tersedia dalam bentuk elektronik saja. Dokumen-dokumen lama telah banyak yang digitalisasi agar dapat diakses secara elektronik. Dengan digitalisasi perpustakaan, maka terjadilah penggandaan informasi dari bentuk tercetak ke bentuk elektronik. Salah satu contoh dari penggandaan informasi ialah, Library and information Science Abstract (LISA), yang dulunya hanya berbentuk tercetak (hard copy), kini telah terbit dalam dua bentuk yaitu tercetak dan CD-ROM.

Format elektronik pada media magnetik mulai mendampingi format cetak pada media kertas ketika sejumlah pangkalan data online mulai didirikan pada pertengahan tahun enampuluhan, kemudian media optik menyusul pada pertengahan tahun delapanpuluhan. Pendapat ini senada dengan apa yang dikemukakan oleh Katz, (1997 : 34), bahwa sebelum tahun 1960-an standar dalam layanan hanyalah menggunakan bahan rujukan tercetak, mulai dari indeks sampai kepada bibbliografi, kemudian menggunakan elektronik database, dan pada pertengahan tahun 1980-an menggunakan compact disc yang disebut CD-ROM. Kedua pendapat tersebut menunjukkan proses digitalisasi informasi yang berkembang dari masa ke masa. Digitalisasi informasi perpustakaan semakin laju berkembang pada akhir tahun delapan puluhan, dan berlanjut hingga saat ini. Secara berangsur-angsur perkembangan format elektronik semakin populer dan koeksis dengan format cetak.

Pada tahap awal format magnetik, dan optik umumnya digunakan untuk menyimpan informasi sekunder seperti bilbiografi dan indeks. Baru pada era selanjutnya format elektronik mencakup teks penuh (full text) dari informasi primer, seperti artikel majalah ilmiah, laporan penelitian, dan sebagainya. Pada era selanjutnya, format elektronik memuat citra penuh (full image), sehingga tampilannya di layar komputer terlihat percis seperti versi cetaknya, dan hasil print outnya terlihat seperti dokumen aslinya.

Digitalisasi informasi perpustakaan dipengaruhi oleh laju pertumbuhan informasi yang ekponensial di satu sisi, serta meningkatnya kemampuan teknologi informasi khususnya komputer. di sisi lain kemampuan media digital menyimpan informasi dalam kapasitas yang sangat besar, mendorong pendigitalisasian informasi cenderung semakin meningkat. Salah satu dampak dari pendigitalisasian informasi ialah terjadinya berbagai perubahan cara mengelola informasi di berbagai pusat informasi, termasuk pada perpustakaan. Kemapanan kertas sebagai media informasi yang selama ribuan tahun menjadi primadonna koleksi perpustakaan, kini ditantang oleh media digital, yang menawarkan cara yang berbeda dalam menyimpan dan menemukan kembali informasi. Oleh karena itu, berbagai perpustakaan dan pusat informasi, telah memperkaya koleksinya dengan berbagai sumber informasi digital. Beberapa perpustakaan di negara maju, bahkan mempunyai lebih 
banyak sumber informasi dalam media digital daripada sumber informasi media cetak. Digitalisasi informasi diperkirakan akan semakin meningkat, seiring dengan kemajuan ilmu pengetahuan dan teknologi.

Digitalisasi informasi perpustakaaan didukung oleh ketersediaan teknologi, baik untuk proses pengalihan, maupun untuk mengakses atau temu kembali. Teknologi yang dimaksud adalah teknologi informasi, terutama di bidang teknologi komputer dan telekomunikasi. Dengan peranan kedua teknologi tersebut, informasi menjadi sesuatu yang bersifat maya, yang dapat diakses dari seantero dunia ini melalui jaringan global yaitu internet.

Berdasarkan hasil observasi awal Peneliti melihat perkembangan digitalisasi informasi perpustakaan dan kemudahan-kemudahan yang disumbangkannya dalam penyediaan maupun penyebarluasan informasi, maka sering memunculkan kekhawatiran pada jati diri pustakawan khususnya pustakawan pada UPT Perpustakaan Universitas Halu Oleo. Ada pihak yang berprasangka bahwa dengan era digital, jasa informasi karya cetak semakin tidak dibutuhkan, dengan demikian keberadaannya diprediksi akan terancam. Ada juga pihak yang lebih ekstrim lagi memprediksi bahwa pada kurun waktu tertentu, orang tidak akan datang lagi ke perpustakaan karena merasa cukup melakukan akses melalui internet dari rumah untuk mencari informasi yang dinginkannya, dengan demikian masa depan perpustakaan dan pustakawan diasumsikan akan buruk, bahkan mungkin akan hilang. Di lain pihak, ada juga yang menyatakan bahwa peran pustakawan semakin diperlukan di era digital, karena dengan ledakan informasi yang sangat besar dan tersebar di berbagai tempat termasuk di berjuta-juta website internet, mengakibatkan pengguna semakin sulit mendapatkan informasi yang relevan dengan kebutuhannya. Banyak perpustakaan yang mengidamkan penerapan digitalisasi koleksi dalam pengelolaannya. Namun demikian tidak semudah yang dibayangkan. Dana yang terbatas dan SDM yang rendah ditengarai sebagai faktor dominan ketidakberdayaan mewujudkan sebuah digitalisasi koleksi diperpustakaan.

Uraian di atas menggambarkan adanya perbedaan pendapat terhadap layanan di era digitalisasi informasi. Untuk menuntaskan pendapat tesebut di atas, maka Peneliti telah melakukan penelitian dengan mengangkat judul, "Perencanaan Digitalisasi Perpustakaan pada UPT Perpustakaan Universitas Halu Oleo".

\section{METODE PENELITIAN}

\section{Lokasi Penelitian}

Penelitian ini dilaksanakan pada UPT Perpustakaan Universitas Halu Oleo. Penelitian ini menggunakan metode kualitatif.

\section{Subjek dan Informan Penelitian}

Berdasarkan judul penelitian ini, maka yang menjadi subyek adalah pustakawan di UPT Perpustakaan Universitas Halu Oleo yang berjumlah 35 orang. Adapun Informan dalam penelitian ini adalah pustakawan di UPT Perpustakaan Universitas Halu Oleo yang berjumlah 3 orang terdiri dari pengelola pustaka elektronik 1 orang dan pustakawan berjumlah 2 orang

\section{Teknik Pengumpulan Data}

Metode pengumpulan data yang di gunakan dalam penelitian ini adalah penelitian lapangan (field Research) yaitu pengumpulan data secara langsung dengan menggunakan beberapa teknik: 
1. Observasi, yaitu untuk pengumpulan data melalui pengamatan langsung di lokasi penelitian,serta peneliu' melakukan pengumpulan data dengan pengamatan secara langsung atau turun langsung di lapangan.

2. Wawancara, merupakan teknik pengumpulan data yang dilakukan dengan cara melakukan tanya jawab secara langsung dengan informan penelitian.

3. Studi Pustaka, merupakan kajian berdasarkan literatur, media atau yang relevan dengan penelitian ini.

4. Dokumentasi, yaitu suatu cam pengumpulan data yang menghasilkan catatancatatan penting serta berhubungan dengan masalah yang akan di tcliti, sehingga akan di peroleh data yang lengkap, sah dan bukan bcrdasarkan perkiraan. Teknik dokumentasi akan peneliti lakukan sebagai pelengkap dari teknik observasi dan lembar kuesioner berikut :

Dalam proses pengumpulan data Penulis menggunakan metode pengumpulan data sebagai

1. Sortir yaitu memilah-milah data menurut urutan kepentingan.

2. Edit yaitu kegiatan mengurutkan data menurut urutan kepentingan.

3. Tabulasi data yaitu kegiatan penyederhanaan data dalam bentuk tabel agar dapat mudah dipahami.

4. Interprestasi data yaitu ada yang telah dianalisis dengan menggunakan metode dijelaskan dan diuraikan secara deksriptif.

\section{Teknik Analisis Data}

Teknik analisis data yang digunakan dalam penelitian ini dilakukan secara kualitatif. Menurut Iskandar (2008), aktivitas dalam analisis data kualitatif yaitu :

1. Data reduction (Reduksi Data) merupakan proses berfikir sintesif yang memerlukan kecerdasan dan keluasan dan kedalaman wawasan yang tinggi. Sedangkan mereduksi data berarti merangkum, memilih hal yang pokok, memfokuskan pada hal-hal yang penting.

2. Data display (penyajian data), penyajian data dapat dilakukan dalam uraian singkat, bagan, hubungan antar kategori, flowchart dan sejenisnya.

3. Conclusion drawing/verification merupakan kesimpulan awal yang dikemukakan masih bersifat sementara dan akan berubah bila ditemukan bukti-bukti yang kuat yang mendukung pada tahap pengumpulan data berikutnya.

\section{HASIL DAN PEMBAHASAN}

Adapun hasil penelitian terkait perencanaan digitalisasi perpustakaan pada UPT Perpustakaan Universitas Halu Oleo akan dijabarkan berdasarkan fokus dalam penelitian ini, yaitu sebagai berikut

\section{Jaringan}

Internet adalah sebuah jaringan komputer dunia yang disambungkan dengan jaringan yang lebih kecil dan bergerak lebih perlahan. Ia mempunyai amat banyak informasi untuk dicapai oleh sesiapa saja, dan menyediakan penghantaran informasi ke seluruh dunia. Pada saat ini, internet boleh disambung melalui pelbagai cara menggunakan layanan komersil atau Penyedia Layanan Internet (Internet Service Provider- ISP) yang semakin bertambah jumlahnya. Internet tidak lagi 
terbatas pada beberapa kalangan, siapa saja yang ada koneksi komputer boleh menggunakan internet. Internet akan terus berkembang dan berevolusi, teknologi yang baru akan terus muncul dan menyebabkan setengah teknologi sekarang menjadi usang. Pertumbuhan internet yang pesat telah mewujudkan cara baru untuk berkomunikasi.

Berdasarkan hasil observasi yang telah dilakukan oleh Peneliti, UPT Perpustakaan Universitas Halu Oleo sudah memiliki akses internet yang cukup. Hal ini terlihat dari beberapa modem, router, dan hub yang terpasang pada ruangan perpustakaan. Dimana PT. Telkom Indonesia atau Indihome cabang Kota Kendari merupakan salah satu penyedia layanan internet atau sering disebut Internet Service Provider yang menyediakan fasilitas internet dengan melakukan kontrak atau sewa dengan pembayaran perbulan/pertahun. Pihak UPT Perpustakaan Universitas Halu Oleo telah berupaya menyediakan akses internet bagi mahasiswa yang berkunjung pada perpustakaan untuk memberikan kemudahan dalam mengakses informasi terkait buku, jurnal maupun referensi lainnya dalam pengembangan ilmu pengetahuan.

Penyediaan akses internet ini dibenarkan oleh salah satu informan penelitian yaitu ibu Vivin Febriani yang berusia 25 tahun dan merupakan pengelola pada UPT Perpustakaan Universitas Halu Oleo, sesuai dengan hasil wawancara yang telah dilakukan bersama Peneliti mengungkapkan bahwa:

"Jaringan atau akses internet yang dimiliki Perpustakaan Universitas Halu Oleo saat ini sudah cukup memadai, seperti yang terlihat bahwa banyaknya mahasiswa yang datang keperpustakaan membaca buku, selain itu juga mahasiswa berkunjung keperpustakaan mengakses internet atau mendownload jurnal untuk menyelesaikan tugas-tugas yang diberikan oleh dosen (Wawancara, tanggal 3 September 2019)"

Dengan adanya akses internet dapat mempermudah mahasiswa dalam mengerjakan tugas perkuliahan mereka dengan cepat, dan informasi yang disediakan oleh internet juga beragam sehingga mahasiswa senang menelusur atau melakukan pencarian informasi menggunakan internet. Pertumbuhan Internet sebagai akibat dari perkembangan browser, dan web grafis yang demikian relevan. Komponen grafis web telah menciptakan media baru untuk banyak perusahaan untuk mengiklankan produk mereka dan untuk berkomunikasi dengan pelanggan mereka. Surat elektronik, atau e-mail merupakan satu lagi fasilitas penting yang dapat digunakan. Oleh karena itu sifat internet yang sentiasa berkembang, pengalaman internet pengguna akan berkembang pula setiap kali mengakses website.

Senada dengan hasil wawancara di atas berikut ini hasil wawancara yang telah dilakukan oleh Peneliti dengan salah informan penelitian yaitu ibu Suriani yang berusia 43 tahun yang juga bekerja pada UPT Perpustakaan Universitas Halu Oleo mengatakan bahwa :

"Untuk saat ini jaringan internet cukup baik untuk melakukan tahapan-tahapan atau melalui proses digitalisasi dokumen (Wawancara, tanggal 3 September 2019)"

Internet adalah sebuah jaringan komputer dunia yang disambungkan dengan jaringan yang lebih kecil dan bergerak lebih perlahan. Ia mempunyai amat banyak informasi untuk dicapai oleh sesiapa saja, dan menyediakan penghantaran informasi ke seluruh dunia. Pada saat ini, internet boleh disambung melalui berbagai cara menggunakan layanan komersil atau Penyedia Layanan Internet (Internet Service Provider- ISP) yang semakin bertambah jumlahnya. Jaringan internet yang digunakan untuk kebutuhan perpustakaan Universitas Halu Oleo sudah cukup bagus, jaringan internet yang digunakan untuk melakukan digitalisasi perpustakaan sudah maksimal, dikarenakan memakai jaringan dari Telkom Indonesia dengan kecepatan $14 \mathrm{Mb} / \mathrm{s}$.

Berdasarkan hasil observasi dan wawancara di atas dapat disimpulkan bahwa UPT Perpustakaan telah menyediakan fasiltas internet dalam tahap perencanaan digitalisasi 
perpustakaan. Dimana dalam perencanaan digitalisasi perpustakaan sangat dibutuhkan akses internet yang cukup baik untuk mendukung proses digitalisasi koleksi pada UPT Perpustakaan Universitas Halu Oleo. Sehingga dapat dikatakan dalam tahapan ini pihak UPT Perpustakaan telah siap untuk melakukan perencanaan digitalisasi perpustakaan. Hal ini merupakan tahapan dasar yang sangat penting dalam proses digitalisasi karena dapat mempermudah proses digitalisasi dokumen dan mengupload hasil digitalisasi secara cepat melalui akses internet.

\section{Fasilitas}

Fasilitas ialah segala sesuatu yang digunakan untuk memudahkan dan memperlancar pelaksanaan segala sesuatu usaha. Fasilitas dapat pula diartikan segala hal yang dapat melancarkan maupun memudahkan pelaksanaan suatu usaha. Fasilitas juga merupakan sesuatu yang memudahkan dan melancarkan suatu usaha tersebut biasanya berupa benda-benda atau uang (Arikunto, 2010).

Berdasarkan hasil observasi yang telah dilakukan Peneliti pada UPT Perpustakaan Universitas Halu Oleo, fasilitas dalam mendukung perencanaan digitalisasi perpustakaan cukup memadai. Hal ini terlihat dari gedung atau ruangan yang digunakan telah dilengkapi dengan alat-alat seperti ; komputer, server maupun scanning yang merupakan fasilitas tahapan digitalisasi perpustakaan pada UPT Perpustakaan Universitas Halu Oleo.

Fasilitas perpustakaan perlu diperhatikan dalam pengelolaan perpustakaan. Fasilitas perpustakaan terdiri dari gedung/ ruang, peralatan dan sarana pendukung lainnya. Hal ini sesuai dengan hasil wawancara yang telah dilakukan oleh Peneliti dengan salah satu informan penelitian yaitu, ibu Darmawati yang berusia 58 tahun mengatakan bahwa :

"Untuk saat ini sudah memadai, begitupula server dan jaringan internet yang dimiliki Perpustakaan universitas Halu Oleo yang mendukung. Untuk fasilitas yang digunakan dalam proses digitalisasi koleksi cukup memadai dikarenakan fasilitas yang dimiliki oleh perpustakaan saat ini ialah: komputer, jaringan internet, server dan scanning (Wawancara, tanggal 3 September 2019)".

Senada dengan wawancara di atas berikut hasil wawancara dengan ibu Vivi Febriani yang juga merupakan informan penelitian ini, mengungkapkan hal yang hampir sama, berikut petikan wawancaranya :

"Saat ini sudah memadai dari segi penyimpanan dan akses telah didukung server perpustakaan yang penyimpanannya lumayan besar dan jaringan internet yang mendukung. Fasilitas yang lain juga sudah memadai untuk proses digitalisasi (Wawancara, tanggal 3 September 2019)".

Fasilitas perpustakaan perlu diperhatikan dalam pengelolaan perpustakaan. Fasilitas perpustakaan terdiri dari gedung/ ruang, peralatan dan sarana pendukung lainnya. Kondisi fasilitas perpustakaan Universitas Halu Oleo untuk saat ini sangat baik misalnya alat scan dan komputer server yang akan digunakan untuk proses digitalisasi masih bagus tidak ada kerusakan yang terjadi. Begitu pula server teknologi dan informasi yang digunakan untuk penyimpanan koleksi digital dan penyimpanannya yang digunakan lumayan besar sehingga masih bisa di tolelir pengunaannya.

Berdasarkan hasil observasi dan wawancara di atas dapat disimpulkan bahwa Fasilitas yang tersedia pada UPT Perpustakaan Universitas Halu Oleo ini telah ada dan cukup memadai untuk memenuhi tahapan perencanaan digitalisasi perpustakaan. Kebutuhan dalam melakukan proses digitalisasi koleksi sudah seharusnya menggunakan fasilitas tersebut di atas guna memperlancar dalam proses penyediaan dan penyebarluasan informasi kepada setiap kalangan khususnya mahasiswa pada Universtitas Halu Oleo.

\section{Pendanaan}


Pendanaan merupakan sesuatu yang sering menjadi kendala bagi pengelola perpustakaan dalam mengembangkan perpustakaannya. Untuk itu, masalah pendanaan harus direncanakan sedini mungkin. Hal tersebut dapat dilakukan melalui sebuah tinjauan terhadap koleksi yang dimiliki dan tujuan pengembangan program-program berupa dokumen perencanaan.

Husnan (2008 : 253-254) menjelaskan keputusan kendanaan perusahaan menyangkut keputusan tentang bentuk dan komposisi pendanaan yang akan digunakan oleh perusahaan. Secara umum, dana dapat diperoleh dari luar perusahaan (external financing) maupun dari dalam perusahaan (internal financing). Keputusan Pendanaan Keputusan pendanaan dapat diartikan sebagai keputusan yang menyangkut struktur keuangan perusahaan (financial structure).

Peneliti berasumsi bahwa proses pendanaan pada UPT Perpustakaan Universitas Halu Oleo merupakan masalah yang cukup serius. Hal ini dalam proses pendanaan membutuhkan sebuah keputusan pendanaan dari pihak Universitas Halu Oleo dalam hubungannya dengan Pemerintah terkait pengalokasian anggaran perpustakaan melalui APBN atau APBD untuk melakukan pendanaan pada UPT Perpustakaan dalam tahapan perencanaan digitalisasi perpustakaan.

Berdasarkan hasil observasi yang telah dilakukan Peneliti, proses pendanaan dalam perencanaan digitalisasi perpustakaan pada UPT Perpustakaan Universitas Halu Oleo merupakan tanggung jawab penyelenggara UPT Perpustakaan. Proses pendanaan dapat dilakukan melalui koordinasi dengan pihak UPT Perpustakaan dalam hubungannya dengan pihak Rektorat Universitas Halu Oleo untuk pendanaan UPT perpustakaan. Hal ini sesuai dengan hasil wawancara dengan salah satu informan penelitian yaitu, ibu Darmawati yang berusia 58 tahun yang bekerja pada UPT Perpustakaan Universitas Halu Oleo mengungkapkan bahwa:

"Biasanya dana perpustakaan menjadi tanggung jawab pihak Rektorat dengan mengalokasikan anggaran perpustakaan kepada pihak Pengelola Perpustakaan, untuk pelaksanaannya tergantung kebijakan pihak Rektorat dalam pengalokasian anggaran tersebut (Wawancara, tanggal 3 September 2019)".

Pendanaan dan anggaran perpustakaan saat ini telah mencukupi untuk operasional kegiatan perpustakaan dalam melakukan digitalisasi koleksi. Dana ini hanya digunakan untuk memperbarui perawatan server yang telah ada, selain itu dana digunakan untuk memeperbesar server jika itu dibutuhkan. Hampir sama dengan yang diungkapkan di atas, ibu Suriani yang berusia 43 tahun juga mengungkapkan bahwa:

"Dana yang didapatkan dari pihak Rektorat Universitas Halu Oleo biasanya digunakan untuk membeli sarana dan prasarana untuk menunjang proses digitalisasi koleksi dan dana biasanya berupa buku koleksi tercetak (Wawancara, tanggal 3 September 2019)".

Pendanaan dalam kegiatan digitalisasi koleksi adalah salah satu faktor penting yang menentukan sukses atau tidaknya kegiatan ini. Pendanaan juga digunakan sebagai acuan apakah kegiatan digitalisasi dapat dilaksanakan, seberapa banyak koleksi yang dapat didigitalkan, serta faktor-faktor teknis lainnya seperti peralatan, media penyimpanan, dan sebagainya, selalu berkaitan dengan masalah pendanaan. Dalam pendanaan, sebelum memulai kegiatan digitalisasi, UPT Perpustakaan Universitas Halu Oleo juga memperkirakan kebutuhan koleksi yang akan didigitalisasikan serta perkiraan dana yang dibutuhkan. Namun, UPT Perpustakaan Universitas Halu Oleo sering mengalami kendala dalam masalah pendanaan dikarenakan dana tidak setiap tahun diadakan dan hal ini juga secara tidak langsung berimbas dengan kegiatan seleksi pada bahan pustaka yang akan didigitalisasikan.

Berdasarkan hasil observasi dan wawancara di atas dapat disimpulkan bahwa pendanaan 
UPT Perpustakaan Universitas Halu Oleo yang digunakan untuk proses digitalisasi ini bersumber dari pihak Rektorat Universitas Halu Oleo. Selain itu, pendanaan UPT Perpustakaan dapat pula bersumber dari Yayasan, Donatur maupun Sponsorship.

\section{Sumber Daya Manusia}

Sumber daya manusia merupakan unsur pendukung utama dalam kegiatan organisasi (lembaga). Kebutuhan SDM untuk mengelola perpustakaan perlu direncanakan dengan mempertimbangkan: jenis kegiatan, kualitas dan kuantitas tenaga, spesialisasi, pemanfaatan teknologi informasi, dana dan tingkat pendidikan pemakai.

Hasibuan (2003: 244), berpendapat bahwa sumber daya manusia memiliki arti keahlian terpadu yang berasal dari daya pikir serta daya fisik yang dimiliki oleh setiap orang. Yang melakukan serta sifatnya dilakukan masih memiliki hubungan yang erat seperti keturunan dan lingkungannya, sedangkan untuk prestasi kerjanya dimotivasi oleh sebuah keinginan dalam memenuhi keinginannya.

Berdasarkan hasil observasi Peneliti, terkait sumber daya manusia pada UPT Perpustakaan Universitas Halu Oleo memiliki latar belakang pendidikan yang cukup baik dengan rata-rata pendidikan pengawai atau pengelolanya merupakan lulusan strata satu (S-1). Pendidikan pustakawan dan pegawai UPT Perpustakaan Universitas Halu Oleo adalah S-1 Perpustakaan (S.IP) dan seharusnya untuk petugas teknologi dan informasinya adalah S-1 Teknologi Informasi (S.Kom).

Hal ini sejalan dengan hasil wawancara dengan salah satu informan penelitian yaitu, ibu Vivin Febriani, yang berusia 25 tahun mengungkapkan bahwa:

"Biasanya bisa sarjana S-1 Komputer dan S-1 Perpustakaan. Dan untuk saat ini tugas kami dibagian automasi atau pengelola dokumen elektronik, ialah hanya melakukan penambahan koleksi digital dan perawatan. Itu saja sih bentuk pemanfaatan teknologi, komunikasi dan informasi (Wawancara, tanggal 3 September 2019)".

Tugas dan tanggung jawab dalam mengelola digitalisasi perpustakaan yaitu mulai dari pengadaan, perawatan dan sirkulasi koleksi digital yang ada. Hampir sama dengan yang diungkapkan di atas, ibu Darmawati juga mengungkapkan hal serupa, berikut petikan wawancaranya :

"Tugas dan tanggung jawab untuk melakukan perawatan disini salah satunya mencakup seringnya menbackup data koleksi digital, mengantisipasi serangan virus, mengecek ketersediaan link dan koleksi digital. Kemudian pengadaan mencakup penambahan koleksi dan melakukan scanning /pemindaian buku cetak untuk dijadikan koleksi digital. Biasanya juga kami mengikuti seminar dsn pelatihan untuk proses digitalisasi dokumen (Wawancara, tanggal 3 September 2019)".

Sumber Daya Manusia semua aspek dalam menejeman SDM haruslah dipertimbangkan tahap awal perencanaan kegiatan digitalisasi. Kegiatan ini bertujuan agar suatu institusi dapat melihat pengaruh dari digitalisasi bahan pustaka bagi organisasi dan SDM. Dalam mempertimbangkan peranan SDM terhadap kegiatan digitalisasi, terdapat dua aspek penting yang harus ditangani. Pertama, siapa yang akan terlibat langsung dalam kegiatan digitalisasi yang akan memindai halaman, mengumpulkan metadata, membuat entri katalog, desain website dan sebagainya. Kemungkinan yang terjadi adalah mayoritas staf yang terlibat dalam proyek digitalisasi adalah staf kontraktor, atau mungkin ditangani oleh vendor di luar institusi. Suatu institusi akan membutuhkan staf yang sesuai dengan kebutuhan proyek digitalisasi, untuk mengelola dan mengevaluasi aktifitas dan perkembangan proyek digitalisasi.

Berdasarkan hasil observasi dan wawancara di atas dapat dikatakan bahwa bentuk pemanfaatan teknologi, informasi dan komunikasi terhadap sumber daya manusia pada UPT Perpustakaan Universitas Halu Oleo adalah hanya menambahkan koleksi dan menyeleksinya. 
Kemudian pegawai perpustakaan Universitas Halu Oleo juga mengikuti seminar atau pelatihan untuk digitalisasi koleksi perpustakaan itu sendiri dengan mengikuti pelatihan di Universitas Halu Oleo. Sedangkan untuk lingkup nasional belum pernah sama sekali.

Dengan demikian Peneliti berasumsi bahwa sumber daya manusia pada UPT Perpustakaan Universitas Halu Oleo cukup mampu untuk melakukan perencanaan digitalisasi perpustakaan. Namun, sebelum tahapan itu dijalankan ada baiknya apabila pihak UPT mengikuti seminar digitalisasi nasional dalam rangka pengembangkan kapasitas dan sumber daya manusia. Selain itu, pihak UPT Perpustakaan Universitas Halu Oleo perlu melakukan penataan kembali khususnya di bidang pendidikan pengawai yang bekerja agar sesuai dengan disiplin ilmu yang dimiliki. Sehingga hasil yang didapatkan sesuai dengan perencanaan sebelum kerja berlangsung.

\section{Pemantauan dan Evaluasi Kinerja}

Pemantauan merupakan proses mencapai tujuan perpustakaan, yang dilakukan dengan cara memantau kinerja layanan secara kontinyu untuk menjamin bahwa strategi yang digunakan mampu mencapai berbagai sasaran yang ditentukan. Kegiatan pembuatan berbagai statistik harus dilakukan secara berkala guna mengetahui arah perkembangan. Evaluasi kinerja merupakan proses umpan balik atas kinerja masa lalu yang berguna untuk mengevaluasi dan meningkatkan produktivitas. Evaluasi kinerja menyediakan informasi mengenai kinerja dalam hubungannya terhadap tujuan dan sasaran. Evaluasi kinerja tahunan hendaknya mencakup semua bidang kegiatan yang dimuat dalam dokumen perencanaan.

Husni (2010 : 971), menyatakan bahwa evaluasi adalah suatu proses untuk menyediakan informasi mengenai hasil penilaian atas permasalahan yang ditemukan". Sedangkan menurut Arikunto (2010: 1) menyatakan bahwa evaluasi sebagai sebuah proses menentukan hasil yang telah dicapai dari beberapa kegiatan yang direncanakan untuk mendukung tercapainya tujuan.

Berdasarkan hasil observasi yang dilakukan Peneliti, dalam rangka mengevaluasi telah dilakukan sesuai dengan ketentuan yang berlaku. Proses evaluasi dilakukan kepada pegawai baik pustakawan maupun bagian automasi pada UPT Perpustakaan Universitas Halu Oleo dengan cara mengevaluasi pemanfaatan koleksi. Hal ini dilakukan setiap saat oleh pustakawan maupun bagian automasi pada perpustakaan.

Berdasarkan hasil wawancara dengan salah satu informan penelitian yaitu oleh ibu Suriani, yang berusia 43 tahun yang merupakan pegawai yang bekerja pada UPT Perpustakaan Universitas Halu Oleo mengungkapkan bahwa:

"Untuk yang melakukan pemantauan dan evaluasi kinerja adalah pustakawan atau pegawai perpustakaan yang bekerja pada bagian automasi pada perpustakaan Universitas Halu Oleo (Wawancara, tanggal 3 September 2019)".

Senada dengan hasil wawancara di atas hal serupa juga diungkapkan oleh ibu Darmawati, yang merupakan salah satu informan dalam penelitian ini mengatakan bahwa :

"Evaluasi pelaksanaan setiap saat, kepala perpustakaan mengevalusi bagaimana jalannya kegiatan atau kinerja yang dilakukan oleh pustakawan, kadang pustakawan melakukan evaluasi pemanfaatan koleksi yang sering digunakan oleh pemustaka (Wawancara, tanggal 3 September 2019)".

Pemantauan dan evaluasi kinerja merupakan proses mencapai tujuan perpustakaan, yang dilakukan dengan cara memantau kinerja layanan secara kontinyu untuk menjamin bahwa strategi yang digunakan mampu mencapai berbagai sasaran yang ditentukan. Kegiatan pembuatan berbagai statistik harus dilakukan secara berkala guna mengetahui arah perkembangan. Evaluasi kinerja merupakan proses umpan balik atas kinerja masa lalu yang berguna untuk mengevaluasi dan 
meningkatkan produktivitas. Evaluasi kinerja menyediakan informasi mengenai kinerja dalam hubungannya terhadap tujuan dan sasaran. Evaluasi kinerja tahunan hendaknya mencakup semua bidang kegiatan yang dimuat dalam dokumen perencanaan.

Berdasarkan hasil observasi dan wawancara di atas dapat disimpulkan bahwa yang melaksanakan pemantauan dan evaluasi kerja adalah kepala perpustakaan, pustakawan atau pegawai perpustakaan yang bertugas pada bagian automasi. Selain pemantauan dan evaluasi kinerja yang dilakukan ada pula evaluasi terhadap tingkat kepuasan pengguna perpustakaan yang dilakukan dengan cara pustakawan melihat judul koleksi apa saja yang sering dilihat atau dibuka oleh pengguna ketika berkunjung keperpustakaan. Dari pemantauan dan evaluasi tersebut maka perpustakaan Universitas Halu Oleo akan menindaklanjuti dengan menambahkan koleksi yang kurang tersebut.

\section{KESIMPULAN}

Berdasarkan hasil penelitian dan pembahasan, Peneliti dapat menarik kesimpulan yaitu : perencanaan digitalisasi perpustakaan pada UPT Perpustakaan Universitas Halu Oleo sejauh ini dari segi indikator jaringan, fasilitas, sumber daya manusia dan pemantauan evaluasi kinerja sudah cukup maksimal. Tetapi dari indikator tersebut adanya indikator yang belum bisa dikatakan maksimal yaitu pendanaan. Proses pendanaan yang berasal dari pihak Rektorat Universitas Halu Oleo dalam hubungannya dengan pihak penyelenggara perpustakaan atau pihak Universitas tidak menjamin proses pendanaannya ada untuk setiap tahunnya, sedangkan perencanaan digitalisasi membutuhkan dana yang cukup besar untuk menunjang prosesnya. Keputusan pendanaan merupakan salah faktor yang cukup serius dalam proses digitalisasi perpustakaan pada UPT Perpustakaan Universitas Halu Oleo.

\section{DAFTAR PUSTAKA}

Afroda, Helmi. 2015. Analisis Proses Pembangunan Dan Pengembangan Perpustakaan Digital (Studi Kasus di Perpustakaan UII). Skripsi. Universitas Islam Indonesia

Arikunto, S. 2010. Prosedur Penelitian Suatu Pendekatan Praktik. Jakarta : Rineka Cipta.

Darmono. 2007. Perpustakaan Sekolah: Pendekatan Aspek Manajemen dan Tata kerja. Jakarta: Grasindo

Driani, Mutiah. 2009. Penelusuran Informasi Siswa Melalui Internet : Studi Kasus di Perpustakaan MAN Insan Cendekia Serpong. Skrips. Universitas Islam Negeri Syarif Hidayatullah. Ilmu Perpustakaan

Handoko, Hani. 1993. Dasar-dasar Manajemen Produksi dan Operasi. Cetakan ketujuh. Yogyakarta: BPFE

Harjanto. 2008. Perencanaan Pengajaran. Jakarta: Rineka Cipta

Hasibuan, Malayu. S.P. 2003. Manajemen Sumber Daya Manusia. Jakarta: PT. Bumi Aksara.

Herlina. 2014. Pembinaan dan Pengembangan Perpustakaan, Palembang: Noer Fikri offset.

Husnan, Suad. 2008. Manajemen Keuangan : Teori dan Penerapan Buku 1. Edisi 4. BPFE. Yogyakarta.

Husni, Lalu. 2010. Pengantar Hukum Ketenagakerjaan Indonesia Edisi Revisi. Raja Grafindo Persada. Jakarta.

Iskandar. 2008. Metodologi Penelitian Pendidikan Dan Social (Kualitatif Dan Kuantitatif). Jakarta: Gaung Persada Press

Katz, William A. 1997. Introduction To Reference Work. Vol. I.: Basic information source. New York: McGraw -Hill. 
Laksana, Deddy Award Widya. 2015. Scan Dan Pracetak. Fakultas Ilmu Komput

am Studi TID3.

Lasa HS. 2007. Manajemen Perpustakaan Sekolah, Yogyakarta: Pinus Book. Publisher.

Latifah, Arni. 2016. Perilaku Pemustaka Dalam Penelusuran Informasi Di Perpustakaan STTNBATAN Yogyakarta. Skripsi. Universitas Islam Negri Sunan Kalijaga. Ilmu Perpustakaan.

Muhadjir, Noeng. 1996. Metodologi Penelitian Kualitatif. Edisi Ke-3. Yogyakarta: Rake Sarasin.

Pendit, Putu Laxman. 2007. Perpustakaan Digital Persfektif Perguruan Tinggi. Jakarta: Sagung Seto.

Pidarta, Made. 2005. Perencanaan Pendidikan Parsipatori dengan Pendekatan Sistem. Jakarta: Rineka Cipta.

Riky, Hardi. 2016. Analisis Perilaku taka dalam Penelusuran Informasi di Perpustakaan Daerah Kabupaten Enrekang. Skripsi. Universitas Islam Negeri Alauddin Makassar. Fakultas Adab dan Humaira. Ilmu Perpustakaan

Saleh, Rahman. 2003. Model Perpustakaan Digital di Indonesia Sebuah Usulan. Jurnal Media Pustakawan. Vol. 10 No. 1. Jakarta: Pusat Pengembangan Pustakawan Perpustakaan Nasional RI

Siregar, A Ridwan. 2008. Perpustakaan Digital: Implikasinya terhadap Perpustakaan di Indonesia. Medan: Universitas Sumatera Utara.

Sismanto. 2008. Manajemen Perpustakaan Digital. Jakarta: Afifah Pustaka

Sugiyono. 2005. Memahami Penelitian Kualitatif. Bandung: Alfabeta

Sugiyono. 2010. Metode Penelitian Kuantitatif Kualitatif \& RND. Bandung: Alfabeta.

Sulistyo-Basuki. 1993. Pengantar Ilmu Perpustakaan. Jakarta: Gramedia Pustaka Utama.

Sulistyo-Basuki. 2003. Manajemen Arsip Dinamis, Pengantar Memahami dan Mengelola Informasi. Jakarta: Gramedia Pustaka Utama.

Sutarno Ns. 2006. Manajemen Perpustakaan : Suatu Pendekatan Praktik. Jakarta: Sagung Seto.

Swastha dan Irawan. 1990. Manajemen Pemasaran Modern. Yogyakarta: Liberty

Terry, George. 2009. Prinsip-prinsip Manajemen. Jakarta: Penerbit Bumi Aksara

Umam, Akhmad Jumanul. 2015. Penelusuran Informasi Menggunakan Ibra Di Perpustakaan SMP Negeri 5 Yogyakarta. Skripsi. Universitas Islam Negri Sunan Kalijaga. Ilmu Perpustakaan.

Undang-Undang Nomor 43 Tahun 2007 Tentang Perpustakaan. Jakarta: Perpustakaan Nasional RI.

Wahono, Romi Satrio. 2003. Teknologi Informasi Untuk Perpustakaan: Perpustakaan Digital Dan Sistem Otomasi Perpustakaan. Semarang 